\title{
A Descriptive Study on the Usage of Exploratory Laparotomy for Trauma Patients
}

This article was published in the following Dove Press journal:

Open Access Emergency Medicine

\author{
Ali Pooria' \\ Afsoun Pourya ${ }^{2}$ \\ Alireza Gheini' \\ 'Department of Cardiology, Lorestan \\ University of Medical Sciences, \\ Khorramabad, Iran; ${ }^{2}$ Student of Research \\ Committee, Tehran University of Medical \\ Sciences, Tehran, Iran
}

Objective: Laparotomy is commonly indicated in patients presenting blunt or penetrating trauma. This cross-sectional study is designed to evaluate the frequency and the causes of laparotomy following abdominal trauma.

Materials and Methods: The data of 71 patients who underwent laparotomy as a result of abdominal trauma in Shohada Ashayer Hospital, Khorramabad were evaluated and a questionnaire was completed for each patient. All the data were analyzed statistically using SPSS.

Results: Of 71 patients, 61 underwent positive laparotomy whereas, negative laparotomy was performed in 10 patients. The results from this study showed that the most common organ of the injury was spleen $(19.7 \%)$, followed by other solid organs. The small intestine $(16.4 \%)$ was found more prone to injuries in penetrating trauma. Incidence of blunt trauma injury due to road accidents was the greatest $50.82 \%$ and $20 \%$ of penetrating traumas were the result of a firearm.

Conclusion: Abdominal trauma injury is common in our study population where spleen, small intestine and other solid organs are chiefly involved. Indications of laparotomy should be fully examined in order to avoid negative laparotomies and associated complications.

Keywords: trauma, blunt, laparotomy, penetrating

\section{Introduction}

Trauma injuries are one of the main challenges in emergency surgeries. ${ }^{1}$ Abdominal injuries contribute to one of the most significant trauma injuries that require special consideration and protocol for management. ${ }^{2,3}$ Exploratory laparotomy is one of the most commonly performed surgical procedures to determine abdominal injuries. ${ }^{4}$

Blunt trauma injuries are estimated to account for $78.6-95.6 \%$ of all the injuries globally whereas, about $9-15 \%$ of trauma injuries are reported in the abdominal region, ${ }^{5}$ with a high range of morbidity. ${ }^{6}$ It is the most susceptible region to blunt injury and early diagnosis is important in order to prevent fatality. ${ }^{7,8}$ Detailed anamnesis and clinical examination are usually recommended for the identification of the injury. ${ }^{9}$ Nonetheless, nonoperative management is associated with a lower rate of success and increased risk of mortality.,10

Patients presenting with hemodynamic instability, hemorrhage-mediate hypotension, organ damage and peritonitis as a result of a penetrating injury to the abdomen or diaphragm are commonly known candidates of emergency laparotomy due to the injury. ${ }^{11}$ Management of blunt trauma injury can be demanding. The identification of intra-abdominal injuries is difficult through imaging modalities, therefore, careful consideration should be taken for the indications of laparotomy. ${ }^{12}$
Correspondence: Alireza Gheini Department of Cardiology, Lorestan University of Medical Sciences,

Khorramabad, Iran

Tel/Fax +986633223004

Email gheinialireza.md@gmail.com
Open Access Emergency Medicine 2020:12 255-260 in $\mathbf{D}$ 
A great number of early postoperative morbidities and mortalities are associated with laparotomy for trauma. ${ }^{13,14}$ Furthermore, negative laparotomies also account for complications and prolonged hospitalization. ${ }^{15,16}$

This study is, thereby, designed to identify the pattern of abdominal injuries requiring laparotomy and the usefulness of the procedure to aid diagnosis.

\section{Methods}

This is a cross-sectional (retrospective) study that was conducted on all the patients referred to the Emergency Department of Shohada Ashayer Hospital of Khorramabad. Patients who underwent emergency laparotomy due to abdominal trauma were included in this study. Patients who were managed nonoperatively were exempted from the study along with those who were hemodynamically stable and had a history of multiples traumas.

Records of all the patients were entered into the system and a questionnaire was filled out based on the available information, such as the findings from the laparotomy, cause of the injury, organs involved and demographic data. Laparotomy was considered negative in the case where no injury was identified. The abdomen was examined in the following regions: the large bowel, the small bowel from the cecum to the ligament of Treitz, stomach, diaphragm, liver, spleen, retroperitoneum and lesser sac.

To analyze the data obtained, SPSS 25.0 was used and the frequency and relative frequency tables were expressed as percentages. The study was approved by the ethical committee of Lorestan University of Medical Sciences (REC.LUMS.1381.WI900).

\section{Results}

In this study, 71 patients who underwent emergency laparotomy due to trauma at Shohada Ashayer Hospital were studied. Of these, 61 patients underwent positive laparotomy,

Table I Frequency of Trauma Mechanism in Positive Laparotomy Subjects

\begin{tabular}{|l|l|l|}
\hline The Trauma Mechanism & Frequency & $\begin{array}{l}\text { Frequency } \\
\text { Relative to } \\
\text { Percent }\end{array}$ \\
\hline Blunt trauma due to accident & 31 & 50.81 \\
Blunt trauma due to conflict & 4 & 6.6 \\
Penetrating trauma with a sharp object & 12 & 19.7 \\
Penetrating trauma with a firearm & 14 & 23 \\
\hline Total & 61 & 100 \\
\hline
\end{tabular}

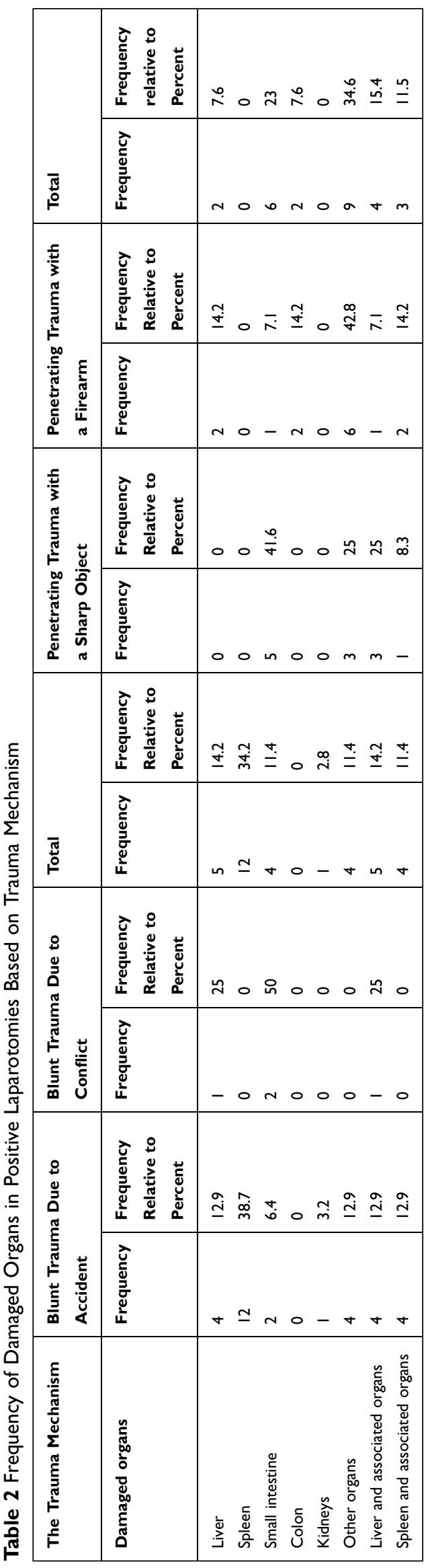


Table 3 Frequency of Damaged Organs in Gender-based Positive Laparotomies

\begin{tabular}{|c|c|c|c|c|}
\hline \multirow{3}{*}{$\begin{array}{l}\text { Gender } \\
\text { Damaged } \\
\text { Organs }\end{array}$} & \multicolumn{4}{|l|}{ Gender } \\
\hline & \multicolumn{2}{|l|}{ Female } & \multicolumn{2}{|l|}{ Male } \\
\hline & Frequency & $\begin{array}{l}\text { Frequency } \\
\text { Relative to } \\
\text { Percent }\end{array}$ & Frequency & $\begin{array}{l}\text { Frequency } \\
\text { Relative to } \\
\text { Percent }\end{array}$ \\
\hline Liver & I & 12.5 & 6 & 11.3 \\
\hline Spleen & 3 & 37.5 & 9 & 17 \\
\hline $\begin{array}{l}\text { Small } \\
\text { intestine }\end{array}$ & 0 & 0 & 10 & 18.9 \\
\hline Colon & I & 12.5 & I & 1.9 \\
\hline Kidneys & 0 & 0 & I & 1.9 \\
\hline $\begin{array}{l}\text { Other } \\
\text { organs }\end{array}$ & I & 12.5 & 12 & 22.6 \\
\hline $\begin{array}{l}\text { Liver and } \\
\text { associated } \\
\text { organs }\end{array}$ & I & 12.5 & 8 & 15.1 \\
\hline $\begin{array}{l}\text { Spleen and } \\
\text { associated } \\
\text { organs }\end{array}$ & I & 12.5 & 6 & 11.3 \\
\hline Total & 8 & 100 & 53 & 100 \\
\hline
\end{tabular}

$50.82 \%$ of patients had blunt trauma due to accident, $6.6 \%$ of patients had blunt trauma due to combat, $19.7 \%$ of penetrating traumas were due to sharp objects, and $23 \%$ underwent emergency laparotomy (Table 1). In patients with blunt trauma, the spleen and liver were the most commonly involved organs, $34 \%$ and $14 \%$, respectively. Whereas, in penetrating trauma $35 \%$ of injuries were in the other organs and the small intestine with $23 \%$ (Table 2). Males were $6.6 \%$ more likely to present injury than females, where also, the spleen was the most commonly injured organ, $38 \%$. Similarly, in the age group of 15 years and less, $57 \%$ of the injuries were reported in the spleen and in 15-30 aged patients, liver and associated organs and small intestine were the most frequently injured organs, $19.3 \%$ and $16.3 \%$, respectively (Table 3). Among patients aged 31-45 years, spleen $(12.9 \%)$ and other organs $(41.6 \%)$ had the greatest prevalence of the injury whereas, among the patients aged 45 and above, the small intestine was the target of trauma injury in $45 \%$ cases (Table 4 ).

Of all patients who had positive laparotomy and died, $14.3 \%$ had liver involvement, $16.7 \%$ presented injury to the spleen, 11\% had liver and associated organs and 14.3\% had a spleen and associated organ injuries (Table 5). Eight point two percent of our patients died where the highest incidence of fatality was associated with the spleen, 16.7\%. In positive laparotomy patients, $11 \%$ had an underlying disease of the small intestine and $12.5 \%$ had an underlying disease of the liver and other organs (Table 6). In the study of patients who underwent laparotomy, $86 \%$ were positive for laparotomy and $14 \%$ negative, where no abdomen-related injury was found (Table 7).

\section{Discussion}

Our study evaluates the pattern of laparotomy in patients with abdominal injuries and reports that spleen blunt traumas have the greatest prevalence and small intestine is

Table 4 Frequency of Damaged Organs in Age-based Positive Laparotomies

\begin{tabular}{|c|c|c|c|c|c|c|c|c|c|c|}
\hline \multirow{2}{*}{$\begin{array}{l}\text { Age } \\
\text { Damaged } \\
\text { Organs }\end{array}$} & \multicolumn{2}{|l|}{$\geq 15$ years } & \multicolumn{2}{|l|}{ 15-30 years } & \multicolumn{2}{|l|}{$31-45$ years } & \multicolumn{2}{|l|}{$\leq 45$} & \multicolumn{2}{|l|}{ Total } \\
\hline & Frequency & $\begin{array}{l}\text { Frequency } \\
\text { Relative to } \\
\text { Percent }\end{array}$ & Frequency & $\begin{array}{l}\text { Frequency } \\
\text { Relative to } \\
\text { Percent }\end{array}$ & Frequency & $\begin{array}{l}\text { Frequency } \\
\text { Relative to } \\
\text { Percent }\end{array}$ & Frequency & $\begin{array}{l}\text { Frequency } \\
\text { Relative to } \\
\text { Percent }\end{array}$ & Frequency & $\begin{array}{l}\text { Frequency } \\
\text { Relative to } \\
\text { Percent }\end{array}$ \\
\hline Liver & $\mathrm{I}$ & 14.3 & 5 & 16.3 & 1 & 8.3 & 0 & 0 & 7 & 11.5 \\
\hline Spleen & 4 & 57.1 & 3 & 9.7 & 3 & 25 & 2 & 18.2 & 12 & 19.7 \\
\hline $\begin{array}{l}\text { Small } \\
\text { intestine }\end{array}$ & 0 & 0 & 5 & 16.3 & 0 & 0 & 5 & 45.4 & 10 & 16.4 \\
\hline Colon & 0 & 0 & I & 3.2 & 1 & 8.3 & 0 & 0 & 2 & 3.3 \\
\hline Kidneys & 0 & 0 & 1 & 3.2 & 0 & 0 & 0 & 0 & I & 1.6 \\
\hline $\begin{array}{l}\text { Other } \\
\text { organs }\end{array}$ & 0 & 0 & 6 & 19.3 & 5 & 41.6 & 2 & 18.2 & 13 & 21.3 \\
\hline $\begin{array}{l}\text { Liver and } \\
\text { associated } \\
\text { organs }\end{array}$ & 0 & 0 & 6 & 19.3 & 2 & 16.6 & 1 & 9.1 & 9 & 14.7 \\
\hline $\begin{array}{l}\text { Spleen and } \\
\text { associated } \\
\text { organs }\end{array}$ & 2 & 28.6 & 4 & 12.9 & 0 & 0 & 1 & 9.1 & 7 & 11.5 \\
\hline
\end{tabular}


Table 5 Frequency of Damaged Organs in Death-based Positive Laparotomies

\begin{tabular}{|l|l|l|l|}
\hline $\begin{array}{l}\text { Age } \\
\text { Damaged Organs }\end{array}$ & $\begin{array}{l}\text { All } \\
\text { Items }\end{array}$ & Death & $\begin{array}{l}\text { Percentage } \\
\text { Fatality }\end{array}$ \\
\hline Liver & 7 & 1 & 14.3 \\
Spleen & 12 & 2 & 16.7 \\
Liver and associated organs & 9 & 1 & 11 \\
Spleen and associated organs & 7 & 1 & 14.3 \\
\hline Total & 35 & 5 & 56.3 \\
\hline
\end{tabular}

Table 6 Frequency of Damaged Organs in Underlying Diseasesbased Positive Laparotomies

\begin{tabular}{|l|l|l|l|}
\hline Underlying Diseases & \multirow{2}{*}{$\begin{array}{l}\text { Total } \\
\text { Damaged Organs }\end{array}$} & Case & \multicolumn{2}{|l|}{ Underlying Diseases } \\
\cline { 3 - 4 } & & Frequency & $\begin{array}{l}\text { Frequency } \\
\text { Relative to } \\
\text { Percent }\end{array}$ \\
\hline $\begin{array}{l}\text { Small intestine } \\
\text { Liver and associated organs }\end{array}$ & 8 & $\mathrm{I}$ & $\mathrm{II}$ \\
\hline Total laparotomy cases & $7 \mathrm{I}$ & 2 & 2.5 \\
\hline
\end{tabular}

Table 7 Frequency of Laparotomies Patients Due to Trauma in Terms of Positive and Negative Laparotomy

\begin{tabular}{|l|l|l|}
\hline $\begin{array}{l}\text { Performed } \\
\text { Laparotomies }\end{array}$ & Frequency & $\begin{array}{l}\text { Frequency Relative to } \\
\text { Percent }\end{array}$ \\
\hline Positive & 61 & 86 \\
Negative & 10 & 14 \\
\hline Total & 71 & 100 \\
\hline
\end{tabular}

commonly involved in penetrating injuries. A study by van Gool et al, reported that car accidents are the most common cause of trauma injury and stab wounds have the highest incidence of penetrating injury. Nonetheless, they also presented laparotomy-associated complications in these patients, which is one of the limitations of this study. ${ }^{13}$ Here we report, firearm and vehicle accidents as the most prevalent types of penetrating and blunt trauma injuries. In a recent case-report, it was reported that among the cases of blunt trauma injuries where three patients had spleen and kidney injury, and two of them had herniation injuries. ${ }^{11} \mathrm{We}$ did not find any hernial injury in our study, and spleen injury was the most prevalent blunt injury in this study.

However, recent findings have also indicated that in the modern period, imaging modalities and several biomarkers can be used to detect trauma, and the use of laparotomy is not mandated, owing to its complications. ${ }^{17}$ Moreover, Simon et $\mathrm{al}^{18}$ reported that laparoscopy for penetrating wound management can reduce the need for negative laparotomy. Discrepancies in the studies are reported regarding the complications associated with negative laparotomy. ${ }^{6,15,19}$ Studies have also shown that in the cases of penetrating stab wound trauma, nonoperative management might fail in $56 \%$ of the cases and laparotomy is likely to be mandatory. ${ }^{20}$ In a study conducted in 1998 at a Russian university, 572 patients with penetrating abdominal injuries were studied where 185 patients with unstable hemodynamic status underwent emergency laparotomy of which 183 had intraperitoneal organ damage. The most common organs involved were the intestines, the spleen, and the liver, respectively. The remaining 387 patients with a negative clinical examination underwent a physical examination for fasciitis rupture, and 151 patients had a negative response to physical examination. ${ }^{14}$ Similarly, the small intestine was among the most affected organ $(23 \%)$ in the penetrating trauma in our study. In a study in Ghana, Ohene-Yeboah et $\mathrm{al}^{21}$ reported that stab wounds were the most common cause of abdominal penetrating injury and the small bowel was the most affected organ. Moreover, the firearm was the leading cause of penetrating trauma in our study. Laparotomy is usually performed in gunshot victims, with hemodynamic instability and peritonitis. In the recent findings, cases where patients are stable and do not present with peritonitis, they can be exempted for laparotomy. Furthermore, negative laparotomy is associated with the risk of complications in about $41 \%$ cases. $^{22}$ In a study conducted at the University of Nigeria on 67 patients with blunt and penetrating trauma, 36 suffered from penetrating abdominal injuries, of which 15 (44.4\%) were bullet-injured. The most common organ involved was spleen in the case of blunt trauma (58.8\%) and the most common organ involved in penetrating trauma was the small bowel (52.8\%). It should be noted that the study was focused on male gender only and the average age of the patients was 29. In our study of 61 patients who had a positive laparotomy, 35 patients had blunt trauma with $34.2 \%$ spleen injuries, followed by penetrating trauma of small intestinal trauma (23\%). In our study, $14 \%$ of laparotomies were negative, which is consistent with similar studies in different countries.

\section{Conclusion}

Our descriptive retrospective study identifies the frequencies of trauma, organ involvement, the use of diagnostic laparotomy and mortality among patients with penetrating and blunt trauma injuries. However, the study lacks the comparison with control groups, therapeutic data and the 
complications associated with laparotomy, particularly in negative laparotomy patients. Future studies with detailed analysis and additional parameters are therefore recommended in this area.

\section{Data Sharing Statement}

Data sharing is not applicable to this article as no datasets were generated or analyzed during the current study.

\section{Consent to Participate}

From the under 16 year olds consent was given by a parent or legal guardian and written consent was obtained from other patients.

\section{Consent for Publication}

Not applicable.

\section{Ethical Approval and Consent to Participate}

All procedures performed in this study involving human participants were in accordance with the ethical standards of the Lorestan University of Medical Sciences Committee and with the 1964 Declaration of Helsinki and its later amendments or comparable ethical standards.

\section{Author Contributions}

All authors made a significant contribution to the work reported, whether that is in the conception, study design, execution, acquisition of data, analysis and interpretation, or in all these areas; took part in drafting, revising or critically reviewing the article; gave final approval of the version to be published; have agreed on the journal to which the article has been submitted; and agree to be accountable for all aspects of the work.

\section{Funding}

This research did not receive any specific grant from any funding agency in the public, commercial or not-for-profit sector.

\section{Disclosure}

The authors report no conflicts of interest in this work.

\section{References}

1. Schwartz SI. Principles of Surgery: PreTest Self-Assessment and Review. McGraw-Hill, Health Professions Division; 1999.

2. McSwain NE, Kerstein MD. Evaluation and Management of Trauma. Appleton \& Lange; 1987.
3. Edino S. Pattern of abdominal injuries in aminu kano teaching hospital, kano. Niger Postgrad Med J. 2003;10(1):56-59.

4. Naudé GP, Bongard FS, Demetriades D. Trauma Secrets. Elsevier Health Sciences; 2003.

5. Eastwood D, Feliciano T:DV, Moore EE, Mattox KL (eds). Stamford: Appleton \& Lange. $0838590101 . £ 93.00,1280$ pp. Injury. 1996;27 (7):531.

6. Renz BM, Feliciano DV. Unnecessary laparotomies for trauma: a prospective study of morbidity. J Trauma Acute Care Surgery. 1995;38(3):350-356. doi:10.1097/00005373-199503000-00007

7. Ozkan OV, Justin V, Fingerhut A, Uranues S. Laparoscopy in abdominal trauma. Current Trauma Rep. 2016;2(4):238-246. doi:10.1007/ s40719-016-0067-6

8. Pimentel SK, Sawczyn GV, Mazepa MM, Rosa FGGD, Nars A, Collaço IA. Risk factors for mortality in blunt abdominal trauma with surgical approach. Revista Do Colégio Brasileiro De Cirurgiões. 2015;42(4):259-264. doi:10.1590/0100-69912015004011

9. Cushing BM, Clark DE, Cobean R, Schenarts PJ, Rutstein LA. Blunt and penetrating trauma - has anything changed? Surgical Clinics North America. 1997;77(6):1321-1332. doi:10.1016/S00396109(05)70620-4

10. Feliciano DV, Burch J, Spjut-Patrinely V, Mattox KL, Jordan JGL. Abdominal gunshot wounds. An urban trauma center's experience with 300 consecutive patients. Ann Surg. 1988;208(3):362. doi:10.1097/00000658-198809000-00014

11. Dharap SB, Noronha J, Kumar V. Laparotomy for blunt abdominal trauma-some uncommon indications. J Emerg Trauma Shock. 2016;9 (1):32-36. doi:10.4103/0974-2700.173866

12. Cayten C. Prehospital Management, Triage and Transportation. Penetrating trauma Philadelphia: Williams \& Wilkins; 1996:161.

13. van Gool MH, Giannakopoulos GF, Geeraedts LM Jr, de Lange-de Klerk ES, Zuidema WP. Complications after laparotomy for trauma: a retrospective analysis in a level I trauma centre. Langenbecks Arch Surg. 2015;400(1):83-90. doi:10.1007/s00423-014-1260-0

14. Oreskovich MR, Carrico CJ. Stab wounds of the anterior abdomen. Analysis of a management plan using local wound exploration and quantitative peritoneal lavage. Ann Surg. 1983;198(4):411. doi:10.1097/00000658-198310000-00001

15. Schnuriger B, Lam L, Inaba K, Kobayashi L, Barbarino R, Demetriades D. Negative laparotomy in trauma: are we getting better? Am Surg. 2012;78(11):1219-1223. doi:10.1177/00031348 1207801128

16. Liebenberg N, Maasch A. Penetrating abdominal wounds-a prospective trial of conservative treatment based on physical signs. South African Medical j. 1988;74(5):231-233.

17. Young K, Benson M, Higgins A, et al. In the modern era of ct, do blunt trauma patients with markers for blunt bowel or mesenteric injury still require exploratory laparotomy? Am Surg. 2017;83 (7):722-727. doi: $10.1177 / 000313481708300728$

18. Simon RJ, Rabin J, Kuhls D. Impact of increased use of laparoscopy on negative laparotomy rates after penetrating trauma. $J$ Trauma Acute Care Surgery. 2002;53(2):297-302. doi:10.1097/00005373200208000-00018

19. Crookes BA, Shackford SR, Gratton J, Khaleel M, Ratliff J, Osler T. "Never be wrong": the morbidity of negative and delayed laparotomies after blunt trauma. J Trauma Acute Care Surgery. 2010;69 (6):1386-1392. doi:10.1097/TA.0b013e3181fd6977

20. Clarke DL, Allorto NL, Thomson SR. An audit of failed non-operative management of abdominal stab wounds. Injury. 2010;41(5):488-491. doi:10.1016/j.injury.2009.10.022

21. Ohene-Yeboah M, Dakubo JC, Boakye F, Naeeder SB. Penetrating abdominal injuries in adults seen at two teaching hospitals in ghana. Ghana Med J. 2010;44(3):103-108.

22. Iflazoglu N, Ureyen O, Oner OZ, Tusat M, Akcal MA. Complications and risk factors for mortality in penetrating abdominal firearm injuries: analysis of 120 cases. Int J Clin Exp Med. 2015;8(4):6154-6162. 


\section{Publish your work in this journal}

The Open Access Emergency Medicine is an international, peerreviewed, open access journal publishing original research, reports, editorials, reviews and commentaries on all aspects of emergency medicine. The manuscript management system is completely online and includes a very quick and fair peer-review system, which is all easy to use. Visit http://www.dovepress.com/testimonials.php to read real quotes from published authors.

Submit your manuscript here: https://www.dovepress.com/open-access-emergency-medicine-journal 